\title{
Overview of bat species reported in Albania with the first country records for eight species
}

\author{
Konrad Sachanowicza ${ }^{a}$ Mateusz Ciechanowski ${ }^{\mathrm{b}}$, Alek Rachwald ${ }^{\mathrm{c}}$ and Michał Piskorski ${ }^{\mathrm{d}}$ \\ ${ }^{a}$ Museum and Institute of Zoology, Polish Academy of Sciences, Warsaw, Poland; bepartment of \\ Vertebrate Ecology and Zoology, University of Gdańsk, Gdańsk, Poland; 'Department of Forest Ecology, \\ Forest Research Institute, Raszyn, Poland; 'Department of Comparative Anatomy and Anthropology, Maria \\ Curie Skłodowska University, Lublin, Poland
}

\begin{abstract}
The bat fauna of Albania, a country located in a Balkan glacial refugium and a Mediterranean biodiversity hotspot, has remained poorly studied although as many as 21 species and representatives of three species complexes had been reported before 2003. It was expected that several new species would be added to the country's list of fauna, not only due to their occurrence in adjacent regions but to the splitting of already known taxa into sibling species and the discovery of new, cryptic species. Altogether, we recorded 32 bat species in Albania, including all of those previously reported (21) and 11 new species for the country, as a result of field work conducted in 2003-2012. Here, we report on eight bat species including Rhinolophus mehelyi, Nyctalus lasiopterus, Plecotus kolombatovici, Barbastella barbastellus, Myotis brandtii that had not been reported previously in Albania while three species (Pipistrellus pipistrellus, Plecotus austriacus, Myotis mystacinus) had been reported before changes to their taxonomy and so could be treated only as representatives of a particular species complex (i.e. sensu lato). We greatly extended the known geographic ranges of five species in the south of Europe.
\end{abstract}

\section{ARTICLE HISTORY}

Received 16 October 2014

Accepted 4 June 2015

Online 24 July 2015

\section{KEYWORDS}

Balkans; biodiversity hotspot; Chiroptera; distribution; species checklist

\section{Introduction}

Albania is a Mediterranean biodiversity hotspot and a Balkan glacial refugium (Hewitt 1999), so the bat fauna of this small country could be one of the most diverse in Europe (Ulrich et al. 2007). However, at the end of the twentieth century, this area had been among the least studied in the Balkans (Uhrin et al. 1996). The first data on bats from Albania came from museum specimens of Plecotus auritus and Pipistrellus kuhlii that were collected in 1914-1931 (Gaisler 1970; Spitzenberger et al. 2001; P. Jenkins pers. comm.). The initial surveys, which focused on cave dwelling bats, were conducted in 1959-1960 by Czech and Albanian zoologists and resulted in the first articles covering 13 species (Hanák et al. 1961; Hanák 1964). Additional species (Nyctalus leisleri, Plecotus austriacus sensu lato and Tadarida teniotis) were reported by Lamani (1970), and several new species were added by Czech and Slovak 
zoologists as the result of occasional field work in 1991-1995 (Chytil and Vlašín 1994; Uhrin et al. 1996). The most recent review in 1996 included the 24 species known at that time, currently recognized as 21 species and representatives of three species complexes, with most being reported from single localities. New data on bat ectoparasites have been published recently (Scheffler et al. 2013).

Since the beginning of the twenty-first century, new bat species have been recognized in Europe as the result of either the discovery of cryptic species or radical changes in taxonomy, mainly to the Myotis mystacinus, Myotis nattereri and Pipistrellus pipistrellus complexes as well as the genus Plecotus (Barratt et al. 1997; Benda and Tsytsulina 2000; von Helversen et al. 2001; Spitzenberger et al. 2006; Mayer et al. 2007; Dietz et al. 2009; Salicini et al. 2013), which extended the list of species expected in Albania. As a consequence, several previously reported species (P. pipistrellus, PI. austriacus and M. mystacinus), (Lamani 1970; Uhrin et al. 1996) were actually recognized as representatives of species complexes, so their occurrence in Albania became doubtful and required confirmation.

In 2003-2012, we conducted field work aimed at collecting distribution and other ecological data for the first monograph on Albanian bats, one of the most neglected groups of mammals in the country. So far, the first records of Plecotus macrobullaris (Sachanowicz and Ciechanowski 2006), Pipistrellus pygmaeus (Sachanowicz et al. 2006) and Myotis alcathoe (Niermann et al. 2007) have been published along with data on the parasitism of bats by spinturnicid mites (Sachanowicz et al. 2014). In this paper, we provide a critical overview of the bats that have so far been reported for Albania, provide the first records of eight species new to Albania and compile an accurate checklist for the country.

\section{Material and methods}

We conducted field work in different regions of Albania during eight trips in 2003-2012.

Trips were conducted in 2003 (5-16 August), 2004 (18 April-1 May), 2005 (17 September-3 October), 2006 (8-27 August), 2007 (2-11 August), 2010 (18 April-8 May), 2011 (21 June-12 July) and 2012 (6-17 September) and covered all 12 counties in Albania. Bat localities were discovered mainly during field exploration, and most were visited only once. Bats were netted (also harp-trapped in 2010) mainly at the entrances to underground roosts and over water and forest roads. Daily surveys of potential bat roosts, which were predominantly abandoned military objects, caves and mines, were also conducted. We identified bats to species based on their external characteristics and measurements (Benda and Tsytsulina 2000; Dietz and von Helversen 2004; Dietz et al. 2009) with careful examinations of representatives of similar species and newly recognized taxa. In the case of the $M$. mystacinus individual, dental characters $\left(\mathrm{P}^{3}\right.$ small, less than half of $\mathrm{P}^{2}$, lack of cingular cusp on $\mathrm{P}^{4}$ ) and penis shape (thin and of equal width) allowed for the exclusion of $M$. brandtii whereas forearm length $(34.4 \mathrm{~mm}$ ), non-metric features (long tragus projecting above the ear notch) and coloration (dark, blackish muzzle and ears) allowed us to distinguish the bat from M. alcathoe. For bat species that were difficult to identify based on morphology alone, we collected tissue samples (wing punches stored in $96 \%$ ethanol) for genetic analysis. Additionally, the calls of commuting and foraging bats were recorded using broadband ultrasound detectors (Pettersson D-980 and Pettersson D-1000X) and analysed with BatSound 3.3 software (Pettersson Elektronik AB, Uppsala, Sweden). 
Some calls were harder to identify by the acoustic method, so 24 measurements had been automatically extracted using SonoBat 3.1.4 software and downloaded to the iBatsID online application (http://ibatsid.cloudapp.net/index.html), according to the protocol of Walters et al. (2012). This method allowed us to identify the species and quantify the probability of a correct identification based on artificial neural networks and a pan-European library of reference calls (Walters et al. 2012). For P. pipistrellus, we provided an acoustic record in addition to a record based on morphological characters. Abbreviations: a.s.l., above sea level; ad., adult; juv., juvenile.

\section{Results and discussion}

Altogether, we recorded 32 species: all of those previously reported (21) and 11 new species for the country (Table 1). The first country records of eight species are presented below.

\section{Rhinolophus mehelyi}

Jermë $\left(39^{\circ} 49.671^{\prime} \mathrm{N}, 20^{\circ} 06.872^{\prime} \mathrm{E}, 56 \mathrm{~m}\right.$ above sea level (a.s.l)), 3 May 2010, 1 pregnant $\mathrm{O}$ and $1 \hat{\mathrm{C}} \mathrm{ad}$. harp-trapped inside abandoned military tunnels. In total, 5-10 individuals were observed near a colony of $R$. euryale. These records demonstrate that $R$. mehelyi is a breeding species in Albania.

This is the only known locality of this rarely recorded species in the western Balkans north of central Greece (Hanák et al. 2001). Eastwards, the nearest known localities are in eastern Serbia (Paunović et al. 1998) and northern Macedonia (Kryštufek et al. 1992).

\section{Barbastella barbastellus}

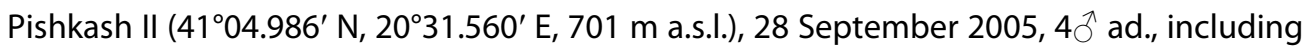
one that was sexually active, netted while entering a small cave in a limestone gorge. The cave could be used for night-roosting and/or swarming based on what is known from the other Balkan regions (Schunger et al. 2004).

The present locality of this species is one of the southernmost on the Balkan Peninsula and demonstrates its wider occurrence in the region, where it has previously been considered to be very local and rare (Paunović et al. 2003). Its nearest previously known localities are in eastern Macedonia (Kryštufek and Petkovski 2003) and central Greece (Hanák et al. 2001). Barbastella barbastellus has been recorded in all of the Balkan countries (Paunović et al. 2003; Pavlinić et al. 2010; Pašić et al. 2013), including Montenegro (A. Rachwald, unpubl. data).

\section{Plecotus austriacus}

Pishkash II (location same as above), 28 September 2005, 10 ad. netted the entrance of a small cave in a limestone gorge. The morphological identification of this species was confirmed by genetic analysis (A. Kiefer, pers. comm.). 


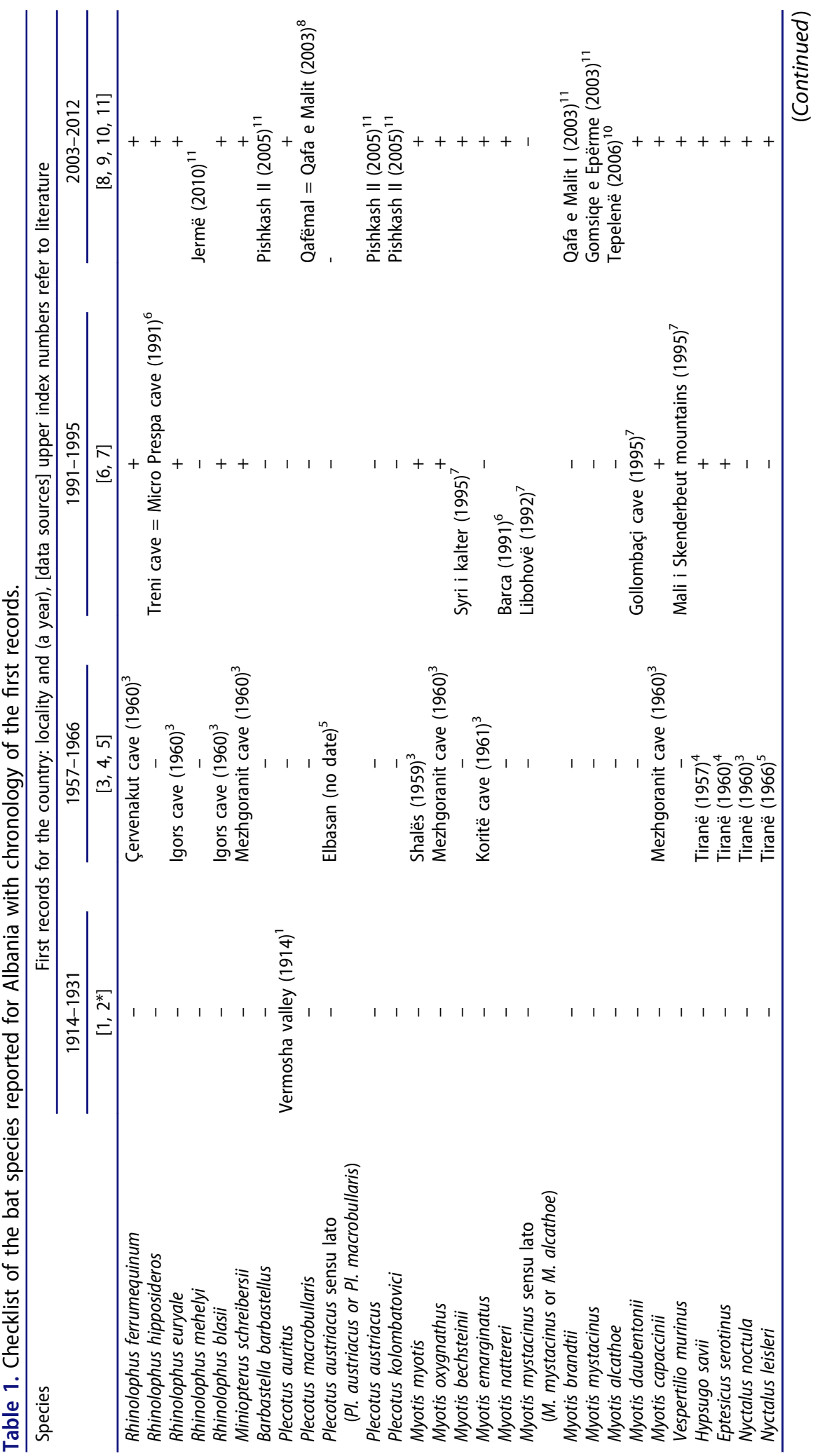




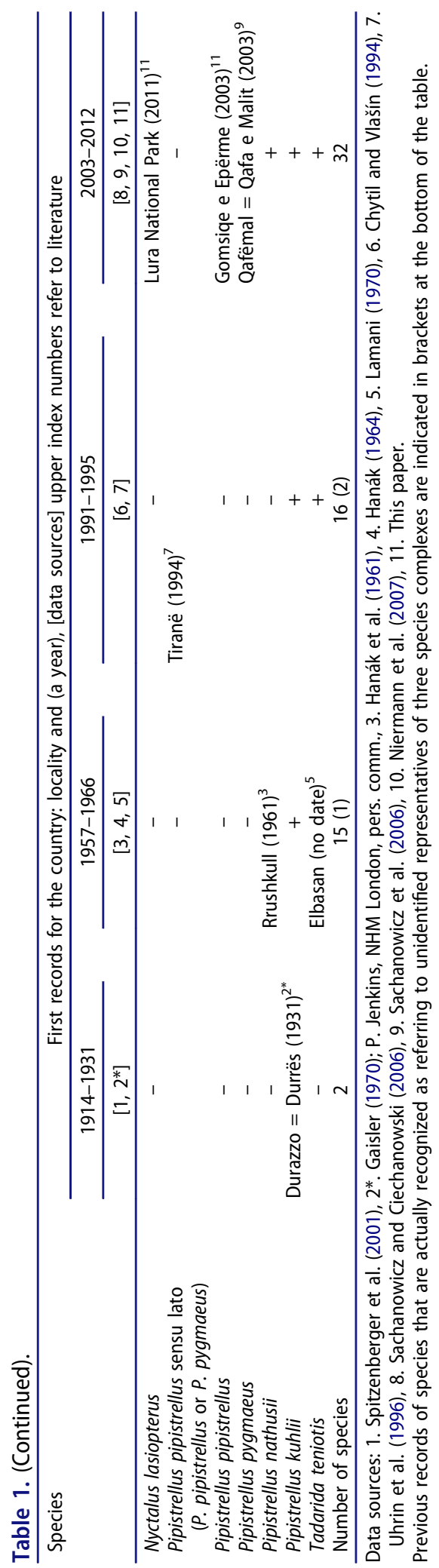


No previous record of Pl. austriacus (Lamani 1970) has been sufficiently documented to confirm the identification of this species (Sachanowicz and Ciechanowski 2006) and exclude a similar, newly recognized species, Pl. macrobullaris (Spitzenberger et al. 2006; Dietz et al. 2009).

\section{Plecotus kolombatovici}

Pishkash II (location same as above), 28 September 2005, 1 sexually active $\delta$ ad. netted at the entrance of a small cave in a limestone gorge. The morphological identification of this species was confirmed by genetic analysis (A. Kiefer, pers. comm.).

The two records of bats from the genus Plecotus (Lamani 1970) could not be assigned to any particular species because of the lack of a detailed description and measurements. For the supposed Pl. kolombatovici record from the Treni Cave, at the Micro Prespa Lake in Albania (24-25 September 2012), no evidence has been provided to support the species identification and exclusion of other Plecotus species (Scheffler et al. 2013). Plecotus kolombatovici has one of the smallest geographic ranges among the European bats; it has only been confirmed in Greece and along the Adriatic coast of Croatia (Đulić 1980; Spitzenberger et al. 2006). The supposed records from Bosnia and Herzegovina are based on external and cranial measurements (Đulić 1980; Červený and Kryštufek 1988) and apparently require confirmation with genetic methods. This new Albanian record indicates a wider occurrence of this species in the southwestern Balkans and its syntopic presence with Pl. austriacus.

\section{Myotis brandtii}

Qafa e Malit I ( $42^{\circ} 05.565^{\prime} \mathrm{N}, 20^{\circ} 06.846^{\prime} \mathrm{E}, 928 \mathrm{~m}$ a.s.I.), 8 August 2003, 1 post-lactating $ᄋ$ ad. netted over a road in mountain mixed forest with old beech and black pine trees.

This locality is one of the southernmost in the western Balkans. Myotis brandtii was previously recorded at two sites in Montenegro (Benda 2004) and, recently, also near the border with Albania in the north of Greece (Papadatou et al. 2011).

\section{Myotis mystacinus}

Gomsiqe e Epërme $\left(41^{\circ} 59.015^{\prime} \mathrm{N}, 19^{\circ} 48.480^{\prime} \mathrm{E}, 344 \mathrm{~m}\right.$ a.s.l.), 5 August 2003, $10^{\Uparrow}$ juv. netted over a river in a rocky gorge.

Due to the discovery of M. alcathoe (von Helversen et al. 2001; Dietz et al. 2009) and the lack of any morphological details allowing for species identification, the only previous record of $M$. mystacinus (Uhrin et al. 1996) may have been either M. mystacinus sensu stricto or M. alcathoe.

\section{Nyctalus lasiopterus}

Lura National Park (4143.039' N, 20¹1.908' E, 1430 m a.s.l.), 28 June 2011, 1 sexually active $\hat{\sigma}$ ad. netted over a road in an old mountain beech forest. 
This record fills the large gap in the distribution of this rarely recorded species in the western Balkans, where it was previously recorded only in Croatia (Kovač et al. 2011) and Greece (Hanák et al. 2001). As N. lasiopterus depends strongly on old hollow trees for roosting (Estók et al. 2007), it may be restricted to difficult-to-access mountain locations in Albania due to the heavy deforestation of lowland areas (Habili et al. 1997).

\section{Pipistrellus pipistrellus}

Gomsiqe e Epërme (location same as above), 6 August 2003, 1 non-lactating $q$ ad. netted over a river in a rocky gorge. Syri i Kalter I (3955.440' N, 20¹1.564' E, 175 m a.s.l.), 23 April 2004, time-expanded echolocation calls of commuting individuals recorded over a karstic spring surrounded by a riparian woodland with oriental plane. The frequency of maximum energy was 43.2-44.5 (mean 44.2, $n=7$ ), and the probability of correct species identification by iBatsID software was 0.93-0.99 (mean 0.97).

Due to the separation of $P$. pipistrellus and P. pygmaeus (Barratt et al. 1997; Dietz et al. 2009) and the lack of any characters allowing for species identification, the only previous record (Uhrin et al. 1996) has to be assigned to P. pipistrellus sensu lato (Sachanowicz et al. 2006).

Although scarcely known until 2003 (21 species and unidentified representatives of three species complexes), the bat fauna of Albania is presently adequately surveyed with 32 recorded species. Our research has confirmed that Albania is one of the European countries with the highest bat species richness. In the geographic Balkans, where 35 bat species are known (Dietz and Kiefer 2014), a greater or equal number of species has only been recorded in Bulgaria with 33 species if an acoustic record of Myotis dasycneme (Boie, 1825) over the Danube river is included (Benda et al. 2003; Mayer et al. 2007; Niermann et al. 2007) and continental Greece with 32 species (Hanák et al. 2001; Mayer et al. 2007). For two of the rarest European bats, R. mehelyi and N. lasiopterus, but also for M. brandtii, Pl. kolombatovici and B. barbastellus, we greatly extended their known geographic ranges in the south of Europe (Dietz et al. 2009). The previous record of M. nattereri in Albania (Chytil and Vlašín 1994) was most probably of this species, which is the only representative of the $M$. nattereri complex confirmed in the Balkans so far (Salicini et al. 2013). Of the two Balkan species not recorded in Albania, Eptesicus nilssonii is only known from single localities in Bulgaria (Benda et al. 2003) and Croatia (Pavlinić and Tvrtković 2003) whereas the known range of M. aurascens (sensu Mayer et al. 2007) covers only a small area of northeast Bulgaria and extends to Romania, Ukraine and Russia (Dietz and Kiefer 2014).

\section{Acknowledgements}

We thank Paulina Jenkins (NHM London) for information about museum specimens of P. kuhlii, Andreas Kiefer for confirmation of our identification of the Plecotus bats as well as Petr Benda and Irek Ruczyński for providing some difficult-to-access literature. We are indebted to Elvana Ramaj (Albanian Ministry of Environment) and Tine Meyer-Cords (UNEP/ EUROBATS) for their kind collaboration. The English of the manuscript was improved by American Journal Experts (AJE). Field work was supported by the EUROBATS Projects Initiative in 2010-2011. 


\section{Disclosure statement}

No potential conflict of interest was reported by the authors.

\section{References}

Barratt EM, Deaville R, Burland TM, Bruford MW, Jones G, Racey PA, Wayne RK. 1997. DNA answers the call of pipistrelle bat species. Nature. 387:138-139.

Benda P. 2004. First record of Myotis aurascens and second record of M. brandtii in Montenegro. Lynx. 35:13-18.

Benda P, Ivanova T, Horáček I, Hanák V, Červený J, Gaisler J, Gueorguieva A, Petrov B, Vohralik V. 2003. Bats (Mammalia: Chiroptera) of the Eastern Mediterranean. Part 3. Review of bat distribution in Bulgaria. Acta Soc Zool Bohem. 67:245-357.

Benda P, Tsytsulina K. 2000. Taxonomic revision of Myotis mystacinus group (Mammalia: Chiroptera) in the western Palearctic. Acta Soc Zool Bohem. 64:331-398.

Červený J, Kryštufek B. 1988. A contribution to the knowledge of the bats of Central and Southern Dalmatia, Yugoslavia (Chiroptera, Mammalia). Biološki Vestnik. 36:17-30.

Chytil J, Vlašín M. 1994. Contribution to the knowledge of bats (Mammalia: Chiroptera) in Albania. Folia Zool. 43:465-467.

Dietz C, Kiefer A. 2014. Die Fledermäuse Europas: kennen, bestimmen, schützen. Stuttgart: Franckh-Kosmos Verlags-GmbH and Co. KG; 394 pp.

Dietz C, von Helversen O. 2004. Illustrated identification key to the bats of Europe. Version 1.0 Tuebingen and Erlangen: Electronic publication; $72 \mathrm{pp}$.

Dietz C, von Helversen O, Nill D. 2009. Bats of Britain, Europe and Northeastern Africa. London: A\&C Black; 398 pp.

Đulić B. 1980. Morphological characteristics and distribution of Plecotus auritus and Plecotus austriacus in some regions of Yugoslavia. In: Proceedings of Fifth International Bat Research Conference; 1978 Aug 6-11; University of New Mexico, Albuquerque. Lubbock: Texas Tech Press; p. 151-161.

Estók P, Gombkötö P, Cserkész T. 2007. Roosting behaviour of the greater noctule Nyctalus lasiopterus Schreber, 1780 (Chiroptera, Vespertilionidae) in Hungary as revealed by radio-tracking. Mammalia. 71:86-88.

Gaisler J. 1970. The bats (Chiroptera) collected in Afghanistan by the Czechoslovak expeditions of 1965-1967. Acta Sc Nat Brno. 4:1-56.

Habili D, Koçi D, Danaj K, Dida M, Vangjeli J, Ruci B, Misja K, Peja N, Haxhiu I, Bego F, Brylski P. 1997. Vezghin ekologjik i pyjeve te virgjer te Shqipërisë [Ecological survey of high forests of Albania]. Tirana: Institute of Forest and Pasture Researches, Institute of Biological Researches and Museum of Natural Sciences; 373 pp. (In Albanian with English summary.)

Hanák V. 1964. Zur Kenntnis der Fledermäusfauna Albaniens. Věst Čs Společ Zool. 28:68-88.

Hanák V, Benda P, Ruedi M, Horáček I, Sofianidou TS. 2001. Bats (Mammalia: Chiroptera) of the Eastern Mediterranean. Part 2. New records and review of distribution of bats in Greece. Acta Soc Zool Bohem. 65:169-279.

Hanák V, Lamani F, Muraj X. 1961. Të dhëna nga përhapja e lakuriqëve të natës (Ordo Chiroptera) në Shqipëri [The results of the research work carried out on the bats in our country]. Bul Univ Shtetëror Tiranës, Ser Shk Natyrore. 3:124-156. (In Albanian, with a summary in English.)

Hewitt G. 1999. Postglacial recolonization of European Biota. Biol J Linn Soc. 68:87-112.

Kovač D, Hamidović D, Fressel N, Drakulić S. 2011. Nyctalus lasiopterus Schreber, 1780 (Chiroptera: Vespertilionidae): first record for Kornati archipelago and first recent capture for Croatia. Mammalia. 75:97-101.

Kryštufek B, Petkovski S. 2003. Annotated checklist of the mammals of the Republic of Macedonia. Bonn Zool Beitr. 51:229-254. 
Kryštufek B, Vohralík V, Flousek J, Petkowski S. 1992. Bats (Mammalia: Chiroptera) of Macedonia, Yugoslavia. In: Horáček I, Vohralík V, editors. Prague studies in mammalogy. Praha: Charles University Press; p. 93-111.

Lamani F. 1970. Lloje të reja lakuriqesh nate në vëndin tonë [Nouvelles especes de chauves-souris dans notre pays]. Bul Shk Natyrore. 2:143-150. (In Albanian, with a summary in French.)

Mayer F, Dietz C, Kiefer A. 2007. Molecular species identification boots bat diversity. Front Zool. 4:4. Niermann I, Biederman M, Bogdanowicz W, Brinkman R, Le Bris Y, Ciechanowski M, Dietz C, Dietz I, Estók P, von Helversen $\mathrm{O}$, et al. 2007. Biogeography of the recently described Myotis alcathoe von Helversen and Heller, 2001. Acta Chiropter. 9:361-378.

Papadatou E, Gremillet X, Bego F, Petkovski S, Stojkoska E, Avramoski O, Kazoglou Y. 2011. Status survey and conservation action plan for the bats of Prespa. Agios Germanos: Society for the Protection of Prespa; $170 \mathrm{pp}$.

Pašić J, Mulaomerović J, Presetnik P. 2013. Results of survey of potential bat hibernacula in Bosnia and Herzegovina in winter 2012/13. Naš Krš. 23:23-35.

Paunović M, Pandurska R, Ivanova T, Karapanda B. 2003. Present knowledge of distribution and status of Barbastella barbastellus (Schreber, 1774) (Chiroptera: Vespertilionidae) on the Balkan Peninsula. Nyctalus (N.F.). 8:633-638.

Paunović M, Paunović A, Ivović M. 1998. Mehely's horseshoe bat Rhinolophus mehelyi Matschie, 1901 new to the Yugoslavian bat fauna. Myotis. 36:115-119.

Pavlinić I, Đaković M, Tvrtković N. 2010. The atlas of Croatian bats (Chiroptera), Part I. Nat Croat. 19:295-337.

Pavlinić I, Tvrtković N. 2003. The presence of Eptesicus nilssonii and Vespertilio murinus in the Croatian bat fauna confirmed. Nat Croat. 12:55-62.

Sachanowicz K, Ciechanowski M. 2006. Plecotus macrobullaris - new bat species for Albanian fauna (Chiroptera: Vespertilionidae). Lynx. 37:241-246.

Sachanowicz K, Ciechanowski M, Rachwald A. 2006. Supplementary notes on the distribution of Pipistrellus pipistrellus complex (Chiroptera: Vespertilionidae) in the Balkans: first records of $P$. pygmaeus (Leach, 1825) in Albania and in Bosnia and Herzegovina. Lynx. 37:247-254.

Sachanowicz K, Krištofík J, Ciechanowski M. 2014. Spinturnicid mites of bats in Albania - host spectrum and morphometrics as a tool of species separation. J Nat Hist. 48:2661-2674.

Salicini I, Ibáñez C, Juste J. 2013. Deep differentiation between and within Mediterranean glacial refugia in a flying mammal, the Myotis nattereri bat complex. J Biogeogr. 40:1182-1193.

Scheffler I, Bego F, Théou P, Podany M, Pospischil R, Hübner S. 2013. Ektoparasiten der Fledermäuse in Albanien - Artenspektrum und Wirtsbindung. Nyctalus (N.F.). 18:84-109.

Schunger I, Dietz C, Merdschanova D, Merdschanov S, Christov K, Borissov I, Staneva S, Petrov P. 2004. Swarming of bats (Chiroptera, Mammalia) in the Vodnite Dupki cave (Central Balkan National Park, Bulgaria). Acta Zool Bulg. 56:323-330.

Spitzenberger F, Piálek J, Haring E. 2001. Systematics of the genus Plecotus (Mammalia, Vespertilionidea) in Austria based on morphometric and molecular investigations. Folia Zool. 50:161-172.

Spitzenberger FP, Strelkov P, Winkler H, Haring E. 2006. A preliminary revision of the genus Plecotus (Chiroptera, Vespertilionidae) based on genetic and morphological results. Zool Scripta. 35:187-230.

Uhrin M, Horáček I, Šíbl J, Bego F. 1996. On the bats (Mammalia: Chiroptera) of Albania: survey of the recent records. Acta Soc Zool Bohem. 60:63-71.

Ulrich W, Sachanowicz K, Michalak M. 2007. Environmental correlates of species richness of European bats (Mammalia: Chiroptera). Acta Chiropter. 9:347-360.

von Helversen O, Heller K-G, Mayer F, Nemeth A, Volleth M, Gombkötö P. 2001. Cryptic mammalian species: a new species of whiskered bat (Myotis alcathoe n. sp.) in Europe. Naturwissenschaften. 88:217-223.

Walters CL, Freeman R, Collen A, Dietz C, Brock M, Jones G, Obrist MK, Puechmaille SJ, Sattler T, Siemers BM, et al. 2012. A continental-scale tool for acoustic identification of European bats. J Appl Ecol. 49:1064-1074. 